\title{
Agronomic performance of mayze hybrids under application of prohexadione-calcium and nitrogen topdressing
}

\author{
João Francisco Costa Carneiro Junior ${ }^{1}{ }^{-}$, Clovis Arruda Souza ${ }^{1 *}{ }^{\oplus}$, Elijanara Raissa Silva ${ }^{1}{ }^{\circ}$, \\ Magaiver Gindri Pinheiro' ${ }^{1}$, Maira Maier Bisato ${ }^{1} \oplus$, Alex Fernando Basilio ${ }^{1} \oplus$, Rodrigo Kandler ${ }^{1} \oplus$, Luis Sangoi ${ }^{1} \oplus$ \\ 1 Universidade do Estado de Santa Catarina, Lages, SC, Brasil, E-mail: jonjf12@hotmail.com; souza_clovis@yahoo.com.br; raissa@agronoma.eng.br; magaiveragronomo@gmail.com;
mairamaier@hotmail.com; afbasilio90@gmail.com; eng.kandler@hotmail.com; luis.sangoi@udesc.br
}

ABSTRACT: The use of prohexadione-calcium (ProCa) is a management alternative to mitigate greater predisposition to vegetative growth. The objective of this study was to evaluate the use of ProCa in combination with two doses of nitrogen fertilizer in cover, in the morphophysiological and productive performance of corn hybrids. Experiments were performed with corn hybrids $A S 1757_{\mathrm{VTPRO}}$ and $\mathrm{AG} 9025_{\mathrm{VTPRO}}$, in a randomized block design, factorial $2 \times 2$, with four replications. The treatments consisted of the application of nitrogen fertilizer in cover, $1 \mathrm{x}$ and $2 \mathrm{x}$ the recommended dose, and in the absence or presence of the application of ProCa. The single effect of ProCa on the hybrid AS1757 ${ }_{\text {VTPRO3 }}$ increased the SPAD index by 20\%; in the AG9025 $5_{\text {VTPROO }}$ hybrid there was a reduction of $8.6 \mathrm{~cm}$ in the height of ear insertion and increments of $2.2 \mathrm{~mm}$ in the stem diameter. The application of ProCa with $2 \times \mathrm{N} \mathrm{ha}^{-1}$ increased, on average, $8.2 \%$ the number of leaves of the AS1757 $7_{\mathrm{VTPRO}}$ hybrid compared to the application to $1 \times \mathrm{N} \mathrm{ha}^{-1}$. There is single effect of ProCa on morphophysiological characteristics in the tested hybrids, but without affecting its grain yield. The use of ProCa in association with $2 \times \mathrm{N} \mathrm{ha}^{-1}$ does not mitigate the vegetative growth in the genotypes, sown late in the South of Brazil.

Key words: growth retardant; plant lodging; vegetative growth; Zea mays L.

\section{Desempenho agronômico de híbridos de milho à aplicação de proexadiona cálcica e nitrogênio em cobertura}

RESUMO: O uso de proexadiona cálcica (ProCa) é uma alternativa de manejo para mitigar maior predisposição ao crescimento vegetativo, no entanto, há poucas informações quanto ao uso de ProCa em associação com a adubação nitrogenada em cobertura. Objetivou-se avaliar o uso de ProCa em associação a duas doses de adubação nitrogenada em cobertura, no desempenho morfofisiológico e produtivo de híbridos de milho. Foram realizados experimentos com os híbridos de milho AS1757 ${ }_{\text {VTPRO3 }}$ e AG9025 ${ }_{\text {VTPRO3 }}$, em delineamento em blocos casualizados, fatorial $2 \times 2$, com quatro repetições. Os tratamentos consistiram na aplicação de adubação nitrogenada em cobertura, $1 \mathrm{x}$ e $2 \mathrm{x}$ a dose recomendada, e na ausência ou presença da aplicação de ProCa. $O$ efeito simples de ProCa no híbrido AS1757 ${ }_{\text {VTPRo3 }}$ incrementou em 20\% o índice SPAD; no híbrido AG9025 $_{\text {VTPRO3 }}$ houve redução em $8,6 \mathrm{~cm}$ na altura de inserção de espiga e incrementos de 2,2 mm no diâmetro do colmo. A aplicação de ProCa com 2x N ha ${ }^{-1}$ incrementou, em média, 8,2\% o número de folhas do híbrido AS1757 $7_{\text {VTPRO3 }}$ em relação a aplicação à $1 \times \mathrm{N} \mathrm{ha}^{-1}$. Há o efeito simples de ProCa sobre características morfofisiológicas nos híbridos testados, mas sem afetar 0 rendimento de grãos. $\mathrm{O}$ uso de ProCa em associação a $2 \mathrm{x} \mathrm{N} \mathrm{ha}^{-1}$ não mitiga o crescimento vegetativo nos genótipos utilizados, semeados em época tardia na Região Sul do Brasil.

Palavras-chave: fitorregulador; acamamento de plantas; crescimento vegetativo; Zea mays L.

* Clovis Arruda Souza - E-mail: souza_clovis@yahoo.com.br (Corresponding author)

Associate Editor: Adônis Moreira 


\section{Introduction}

Corn (Zea mays L.) is one of the most consumed and produced cereals worldwide, and its productive potential is linked to factors such as the chemical composition and nutritional value of the grain. In Brazil, cultivation ranges from small properties to large commercial plantations; according to Conab (2020), national production of 100.48 million tons is estimated for the $2019 / 2020$ harvest, with average productivity of $5.5 \mathrm{t} \mathrm{ha}^{-1}$; obtained through the set of management techniques to achieve high productive ceilings. One technique is the use of modern hybrids coupled with modifications in plant arrangement, intensification of nitrogen fertilization, and the use of products aimed at maximizing productivity (Kolling et al., 2019).

Therefore, most Brazilian soils are inefficient in the availability of nitrogen (N) required by some crops, which is required in larger quantities in Poaceae, requiring nitrogen application at sowing and top dressing, in order to complement the needs in periods of greater crop demands (Sangoi et al., 2016). The recommendation of the nitrogen fertilizer dose should be as accurate as possible to express the maximum yield potential and a good cost/benefit ratio, in order to provide a lower environmental impact. Nutritionally some of the beneficial effects provided by nitrogen fertilization highlight the essentiality in physiological processes, maintenance of photosynthetic activity, growth and development of reproductive sinks (Taiz et al., 2017), however, the increased availability of $\mathrm{N}$ intensifies vegetative growth and promotes undesirable adversities, such as lodging, as well as environmental adversities such as soil acidification, and contamination of the water table via leaching and erosion.

Excessive growth increase, in plant height and ear insertion height, are morphological characteristics that may indicate pre-disposition to lodging and breaking of corn plants, intensified when combined with early summer sowing in the South region of Brazil, corresponding to the end of the agro-climatic zoning period for the Campos de Lages microregion, and under high plant density, due to lower water availability, incident intensity of solar radiation during the crop cycle, increased intraspecific competition for environmental resources (water, light, and nutrients), resulting in reduced productivity and grain quality (Kolling et al., 2019).

In species of the Poacea family, phytoregulators are commonly used, which have been an ally in strategies to obtain high grain yields in high-tech crops. The use of phytoregulators inhibiting the biosynthesis of active gibberellins acts on plant architecture, reduces lodging and plant breakage, favors the absorption of solar radiation, alters leaf dimensions and thatch diameter, provides a larger root system benefiting water and nutrient uptake (Pricinotto et al., 2015), and mitigates abiotic effects that reduce productivity (Rademacher, 2015).

Among the active ingredients available is prohexadionecalcium (ProCa) (3-oxide-4-propionyl-5-oxo-3-cyclohexenecarboxylate), efficient phytoregulator to control branch growth and increase productivity in fruit trees, being registered in Brazil for use in wheat, oats, barley, rye, triticale (Mapa, 2019). According to Rademacher (2016) the ProCa molecule alone or in association with other phytoregulators inhibiting gibberellin biosynthesis currently represents the best technical solutions for controlling vegetative growth and plant lodging. Its use has already been tested on Oryza sativa L. (Na et al., 2011), Triticum aestivum L. (Stefen et al., 2014), Linum usitatissimum L. (Kim et al., 2018), and Zea mays L. (Pinheiro et al., 2018; Carneiro Junior et al., 2021).

Nitrogen fertilization is an important practice to increase the grain yield of corn and the phytoregulator ProCa is used in Poaceae to control the vegetative growth of plants; however, there is little information regarding the use of ProCa application in association with the intensification of nitrogen fertilization and its influence on the morphophysiological and productive behavior of corn plants. The hypothesis of this research is based on the fact that the application of ProCa at the beginning of the accelerated elongation period in corn plants, in association with twice the recommended nitrogen fertilization, increases productive responses in the different hybrids, restricts vegetative growth, confers higher values of stalk diameter, reduces lodging and plant breakage, and maintains photosynthetically active leaves during the reproductive phase.

Thus, the objective was to evaluate the influence of the use of the phytoregulator ProCa in association with two doses of nitrogen fertilization applied in the vegetative phase, in the responses of morphophysiological and productive parameters of two corn hybrids sown in early summer in southern Brazil.

\section{Materials and Methods}

The experiments were conducted in the experimental area of the Universidade do Estado de Santa Catarina Centro de Ciências Agroveterinárias (UDESC - CAV), in the period from December 28, 2018 (sowing) to May 15, 2019 (harvest), in the municipality of Lages, SC, Brazil, located in the southern plateau region of the state of Santa Catarina, under geographical coordinates of $27^{\circ} 47^{\prime} 03^{\prime \prime} \mathrm{S}, 50^{\circ} 18^{\prime} 07^{\prime \prime} \mathrm{W}$ and average altitude of $930 \mathrm{~m}$. According to the Köppen-Geiger classification, the region climate is of type $\mathrm{Cfb}$, mesothermal, with mild summers, average temperatures of the hottest month below $22{ }^{\circ} \mathrm{C}$, and well distributed rainfall during the year.

The meteorological data were obtained from the Instituto Nacional de Meteorologia (INMET), collected at the automatic station at the experimental station of the Empresa de Pesquisa Agropecuária e Extensão Rural de Santa Catarina (EPAGRILages). The information about maximum and minimum temperatures, and daily rainfall during the experiment are presented in Figure 1.

The soil of the experimental area is classified as Humudepts (cambisol, humic-aluminic) (Santos et al., 2013). The chemical properties of the soil, in the $0-20 \mathrm{~cm}$ layer, according to the soil analysis performed in November 2018, are described in Table 1. Maintenance fertilization consisted of $505 \mathrm{~kg} \mathrm{ha}^{-1}$ of NPK 


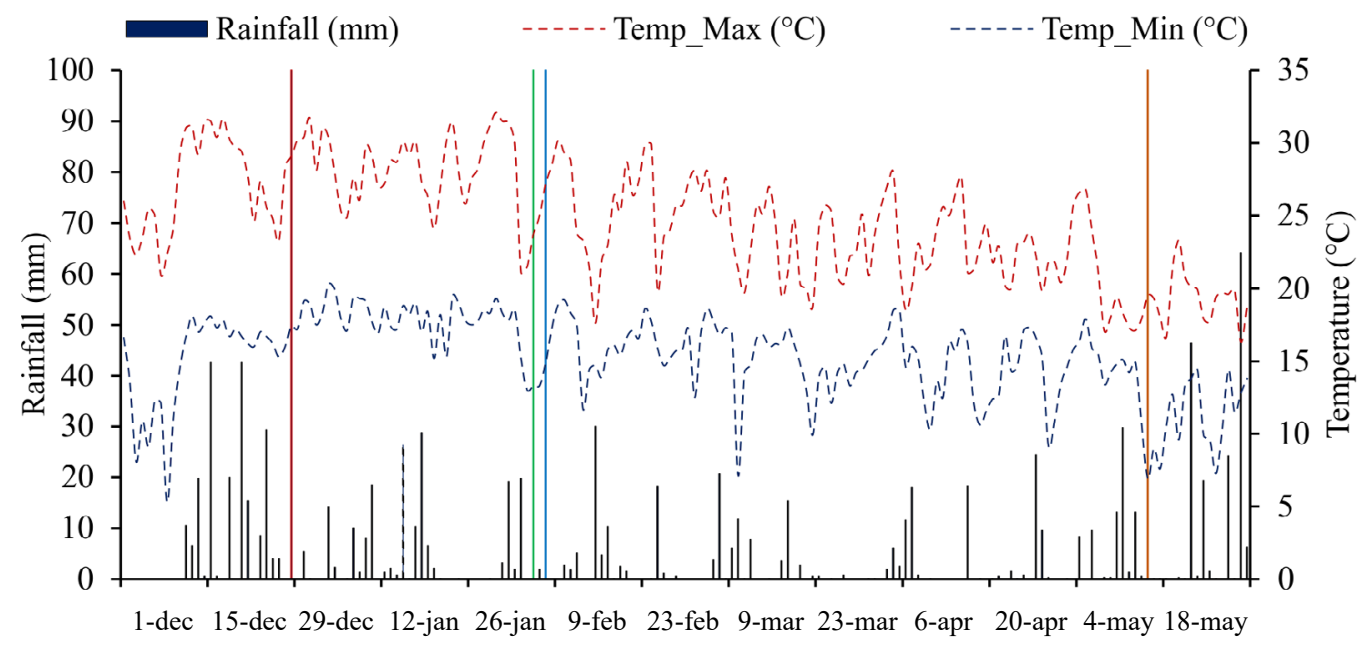

Cycle length (days)

1;2/ Vertical red lines indicate the sowing and harvest dates of the experiments, respectively.

${ }^{3 /}$ Vertical green and blue lines correspond to the application dates of prohexadione calcium (plants at phenological stage V7), in corn hybrids AG9025 ${ }_{\text {VTPRo3 }}$ and AS1757 $_{\text {VTPRo3 }}$, respectively.

Figure 1. Daily rainfall and maximum and minimum temperatures during the experiment (sowing in Dec., $28^{\text {days; }}$ harvest in May, 15 $5^{\text {days }}$. Lages, SC, Brazil, 2019.

Table 1. Chemical analysis of the soil of the experimental area of UDESC-CAV. Lages, SC, Brazil, 2019.

\begin{tabular}{|c|c|c|c|c|c|c|c|c|c|}
\hline Clay & v & OM & \multirow{2}{*}{$\underset{\left(\mathrm{H}_{2} \mathrm{O}\right)}{\mathrm{pH}}$} & $\begin{array}{c}\text { P } \\
\text { Mehlich-I }\end{array}$ & K & $\mathrm{Ca}$ & Mg & $\mathrm{H}^{+}+\mathrm{Al}^{+3}$ & $\begin{array}{c}\text { CEC } \\
(\mathrm{pH} 7)\end{array}$ \\
\hline \multicolumn{3}{|c|}{$(\%)$} & & \multicolumn{2}{|c|}{$\left(\mathrm{mg} \mathrm{dm}^{-3}\right)$} & \multicolumn{4}{|c|}{$\left(\mathrm{cmol}_{\mathrm{c}} \mathrm{dm}^{-3}\right)$} \\
\hline 48 & 83 & 3.3 & 6.4 & 26.1 & 104 & 10.1 & 5.2 & 3.3 & 18.8 \\
\hline
\end{tabular}

$\mathrm{V}=$ base saturation; $\mathrm{OM}=$ organic matter; $\mathrm{P}$ Mehlich-I = official phosphorus extraction from soil in Southern Brazil; $\mathrm{CEC}=$ cation exchange concentration; $\mathrm{pH}=$ hydrogen potential; $\mathrm{H}^{+}+\mathrm{Al}^{3+}=$ exchangeable aluminum.

fertilizer, formulation 5-20-10 (N- $\left.\mathrm{P}_{2} \mathrm{O}_{5}-\mathrm{K}_{2} \mathrm{O}\right)$, distributed close to the crop rows, following the technical recommendations of CQFS-RS/SC (2016), aiming to obtain yields of $12,000 \mathrm{~kg} \mathrm{ha}^{-1}$.

Each experimental unit consisted of three 7.5-m rows, with 0.4-m spacing between rows. The central line was considered the useful area, totaling $3 \mathrm{~m}^{2}$, discarding the two outer rows. The soil was prepared in the conventional way, plowing and harrowing. Sowing was performed mechanically at a density of 100,000 plants ha $^{-1}$, depositing the seeds at a distance of $0.25 \mathrm{~m}$, using the hybrids AS1757 ${ }_{\mathrm{VTPRO}^{3}}$ early cycle; and AG9025 VTPRO3, , super-early cycle, both characterized by stability in growing environments. When the plants were between the phenological stages of two to three fully expanded leaves V2 and V3, respectively, thinning was carried out to adjust the desired population densities. To obtain precise management indications and specific recommendations of the phytoregulator alone or in association with nitrogen cover dressing, each hybrid (AS1757 $7_{\text {VTPRO3 }}$ and AG9025 $5_{\text {VTPRO3 }}$ ) consisted of one experiment and were analyzed separately.

The experimental design adopted was in randomized blocks, in a $2 \times 2$ factorial scheme, with four repetitions. The first factor consisted of two doses of nitrogen in the form of urea, $274 \mathrm{~kg}$ of $\mathrm{N} \mathrm{ha}^{-1}$, applied in a single dose at the V4 stage; and $548 \mathrm{~kg}$ of $\mathrm{N} \mathrm{ha}^{-1}$, divided equally into two seasons, at the V4 and V6 stages of the Ritchie et al. (1993) scale. These doses are equivalent to $1 \times$ and $2 \times$ times, respectively, the recommended nitrogen dose for obtaining the desired yield potential of $12 \mathrm{tha}^{-1}$. The second factor represented two doses of the growth phytoregulator ProCa, being the doses: 0 (no application) and $100 \mathrm{~g}$ active ingredient (a.i.) ha ${ }^{-1}$ of the commercial product (c.p.) Viviful ${ }^{\circ} \mathrm{WG}$, applied in a single dose, at the V7 stage using a constant pressure sprayer of $30 \mathrm{lb} \mathrm{pol}^{-2}$, pressurized by $\mathrm{CO}_{2}$, calibrated for a spray volume equivalent to $200 \mathrm{~L} \mathrm{ha}^{-1}$.

Weeds were controlled in post-emergence when the plants were at the V3 and V6 stages, using the product based on atrazine + simazine (Primatop ${ }^{\circledR}$ ) at a dose of $6 \mathrm{~L}$ ha ${ }^{-1}$ c.p., and mesotrione (Callisto ${ }^{\circledR}$ ) at a dose of $300 \mathrm{~mL} \mathrm{ha}^{-1}$ c.p., respectively. The insecticides were also applied, with thiamethoxam and lambda-cyhalothrin (Engeo Pleno ${ }^{\circledR}$ ) at a dose of $250 \mathrm{~mL} \mathrm{ha}^{-1}$ c.p, when the plants were at the V3 stage, and imidacloprid and beta-cyfluthrin (Connect ${ }^{\circledast}$ ) dose of $500 \mathrm{~mL} \mathrm{ha}{ }^{-1}$ c.p. at the V5 stage, both for the control of the green-bellied bug (Dichelops furcatus) and the cartridge caterpillar (Spodoptera frugiperda), all performed following recommendations for the corn crop.

The relative chlorophyll content was determined by reading with a Konica Minolta ${ }^{\circ}$ SPAD (Soil Plant Analysis Development) 502 plus portable meter, using readings in the middle third of the index leaf; and the normalized difference vegetation index (NDVI), taken at the plant canopy leaves, the third or fourth leaf above the ear, using the PlantPen NDVI-300 handheld sensor. Phytometric evaluations were performed, such as plant height (distance measured from the surface to the tip of the stalk), and ear insertion (measured from the distance from the soil surface to the main ear), both measured with the aid 
of a tape measure in $\mathrm{cm}$; stalk diameter (determined at the second internode above ground, from the base of the plant) was determined using a digital pachymeter; A ruler graduated in $\mathrm{cm}$ was used to measure the length and width of the leaf opposite the ear, and the leaf above the ear. Also, the total number of green leaves was determined by direct counting on the plant. All evaluations were measured on plants that were at the R1 stage (budbreak and pollination) on five plants with previously identified phenological and morphological uniformity at the V5 stage in each experimental unit.

At the physiological maturity of the crop, the number of lodged and broken plants was counted within the useful area of the plot, by dividing the number of lodged and broken plants by the total number of plants in the useful area multiplied by 100 . Being considered bedridden plants, whose stalk formed an angle of less than 45으 with the surface of the soil and broken plants that presented rupture of the stalk below the ear.

Harvesting was performed mechanically on May 15, 2019, collecting all ears contained in the useful area and evaluating the productive performance, obtained by counting the final plant population and respective number of ears per plant. Then the grain yield components were determined, by collecting five ears of grain from the useful area of the plot to check the number of grains per ear and thousand grains weight, as well as the hectoliter weight. To determine the grain yield, in tons ha- ${ }^{-1}$, the grains were placed in paper bags and stored in an oven, under ventilation and temperature of $65 \stackrel{\circ}{ } \mathrm{C}$, until they reached constant mass. The weights obtained from the dry weight of grain harvested from the useful area of the plots were converted to one hectare, after correction based on $13 \%$ moisture content.

The data were previously tested for homogeneity and normality at 5\% significance level, Bartlett and Shapiro-Wilk, respectively, and then analysis of variance (ANOVA) by the $F$ test at $5 \%$ significance level. The multiple comparisons of means test used was Tukey $(p<0.05)$. Statistical analyses were performed with the statistical software Sisvar version 5.6 for Windows (Ferreira et al., 2014). Pearson correlation analyses between the variables under research were performed using the statistical analysis language and computing environment with R Core Team (2019).

\section{Results}

The results of the analyses of variance for hybrid $\mathrm{AS}_{1757_{\text {VTPRO3 }}}$ report significant effects for the interaction between nitrogen $(\mathrm{N})$ and prohexadione (ProCa) doses for the variables normalized difference vegetation index (NDVI), plant height (PH), number of green leaves (NGL), lodging + breaking index (LBI), number of grains per ear (NGE), and hectoliter weight (HW). As for hybrid AG9025 $5_{\text {VTPRO3 }}$ only the variables number of grains per ear (NGE) and thousand grains weight reported $\mathrm{N} \times$ ProCa interaction (Table 2 ).

The NDVI of hybrid AS1757 ${ }_{\text {VTPRO3 }}$ in the absence of the application of the phytoregulator ProCa and the application of $548 \mathrm{~kg}$ of $\mathrm{N} \mathrm{ha}^{-1}$, corresponding to twice the recommended dose of nitrogen $(2 \times)$, showed an increase of $4.5 \%$ in this index compared to the recommended dose of $\mathrm{N}$. Twice the recommended dose of nitrogen, regardless of the presence and/or absence of ProCa did not show any statistical difference between the means for NDVI. Whereas, at the recommended dose $(1 \times)$ of nitrogen, corresponding to $274 \mathrm{~kg}$ $\mathrm{ha}^{-1}$, the application of ProCa promoted a $3.1 \%$ increase in the vegetative index in relation to the absence of ProCa (Table 3 ).

The $\mathrm{PH}$ showed a difference in relation to the $\mathrm{N}$ fertilization when the phytoregulator was applied to hybrid AS1757 ${ }_{\text {VTPRO3 }}$ (early-cycle). The ProCa product restricted plant height growth at the recommended dose of $\mathrm{N}$, a reduction of 13.6 $\mathrm{cm}$ compared to twice as much N. A restriction of $11.6 \mathrm{~cm}$ in $\mathrm{PH}$ was observed with the application of ProCa at the recommended $\mathrm{N}$ fertilization. There was no influence in $\mathrm{PH}$ to using or not using ProCa with double nitrogen application on the number of green leaves (Table 3).

An increase in green leaves was obtained in hybrid AS1757 ${ }_{\text {VTPRO3 }}$ by applying twice as much nitrogen, in the absence or presence of the application of ProCa in relation to the recommended dose. However, there was a statistical difference only when the phytoregulator was applied, with an average increase of 1.8 leaves in relation to the recommended dose. The application of ProCa also increased 1.1 green leaves compared to no application, but only in association with twice as much nitrogen fertilizer (Table 3).

For hybrid AS1757VTPRO3 the application of ProCa increased an average of 200 grains per ear compared to no ProCa in the double $\mathrm{N}$ fertilization, the association of ProCa with double the dose reported an average of 501.1 NGE. Double the nitrogen fertilization increased by 151 grains per ear compared to the recommended dose of $\mathrm{N}$ in the presence of ProCa for the same hybrid aforementioned above (Table 3). Similar behavior was observed for $\mathrm{HW}$, with an increase

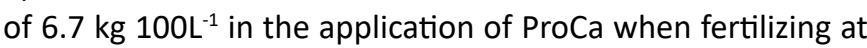

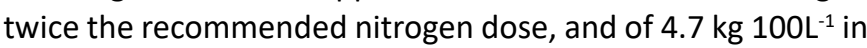
the presence of ProCa in relation to the absence at twice the recommended dose (Table 3).

The number of NGE of hybrid AG9025 ${ }_{\mathrm{VTPRO}}$ showed distinct behavior compared to hybrid AS1757 $7_{\text {VTPRO3 }}$, the recommended dose of nitrogen with ProCa application increased an average of 64 grains per ear compared to twice the recommended dose of $\mathrm{N}$ in hybrid AG9025 $5_{\text {VTPRO3 }}$ (super-early). As for TGW, there was no distinction between the treatments without and with ProCa application. However, the highest thousandgrain weight was obtained in the treatment with double the nitrogen fertilizer cover, both in the absence and presence of ProCa, 44.5 and $40.2 \mathrm{~g}$ higher than the recommended dose, respectively, in hybrid AG9025 ${ }_{\text {VTPRO3 }}$ (Table 3).

The simple effects of the factors on hybrid AS1757 are shown in Table 4. Regarding the simple effect of $\mathrm{N}$ doses, it was observed that the application of twice the amount of nitrogen in covering increased the relative chlorophyll content in the leaves of corn plants of hybrid AS1757 ${ }_{\mathrm{VTPRO3}^{\prime}}$, an increase of $31 \%$. An increase of twice the $\mathrm{N}$ dose in relation to the 
Table 2. Summary of the analysis of variance, mean square values, and significance, for the variables normalized difference vegetation index (NDVI), relative chlorophyll index (SPAD), plant height (PH), ear insertion height (EIH), stem diameter (SD), number of green leaves (NGL), length and width of the leaf opposite the ear (LLO; WLO), length and width of the leaf above the ear (LLA; WLA), Lodging + breakage index (Lodg), number of ears per plant (NEP), number of grains per ear (NGE), thousand grains weight (TGW), grain yield (GY), and hectoliter weight (HW), for hybrids $A S 1757_{\mathrm{VTPRO3}}$ and $\mathrm{AG} 9025_{\mathrm{VTPRO3}}$, subjected to two doses of nitrogen and two doses of prohexadione calcium in the 2018/2019 crop. Lages, SC, Brazil, 2019.

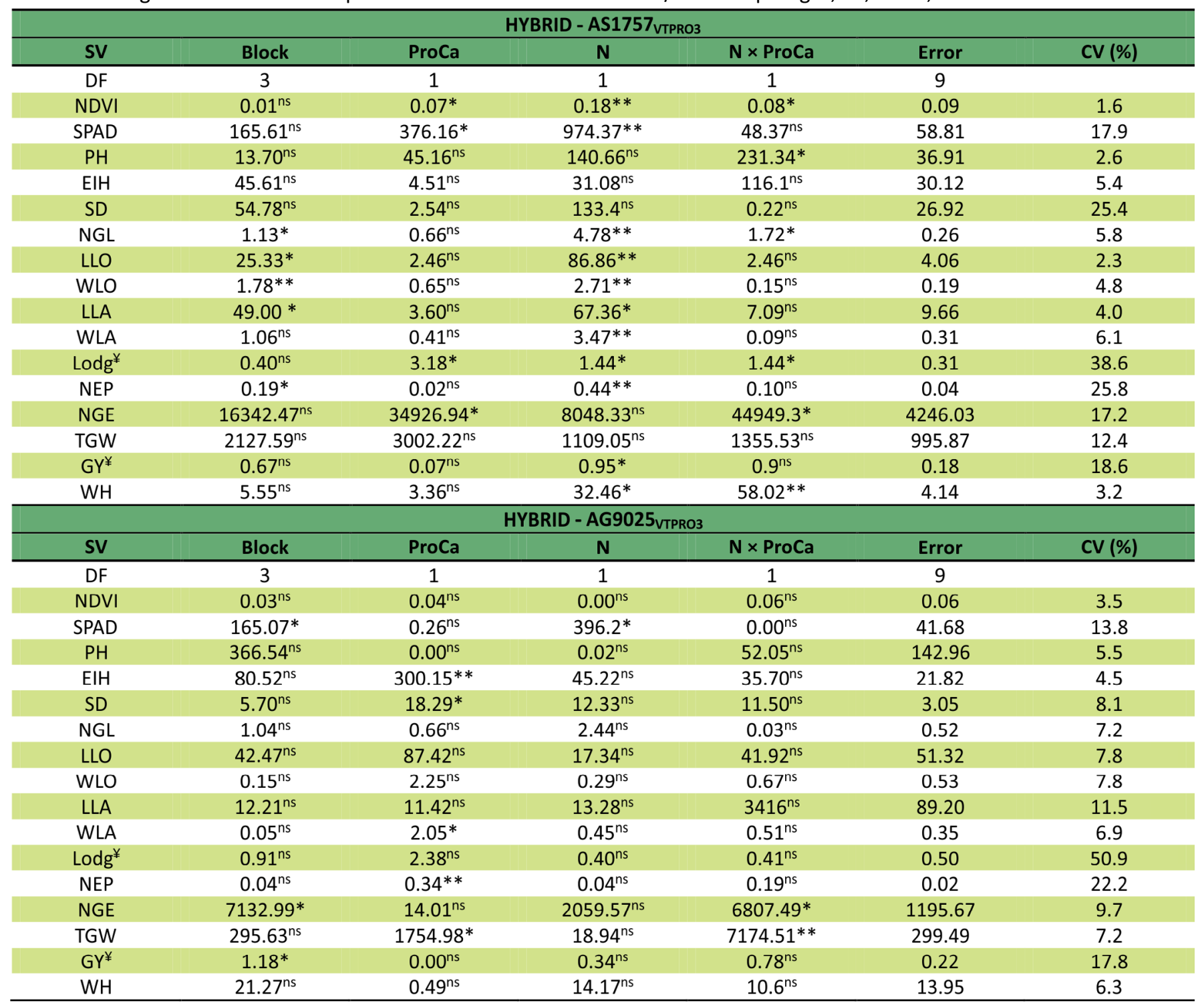

** $e^{*}=$ differ statistically by the F-test at $(p<0.01)$ and $(p<0.05)$, respectively; $n s=$ Not significant $(p \geq 0.05) ;$ SV = sources of variation; DF = degrees of freedom; CV\% = coefficient of variation. ${ }^{*}=$ Indicates that the values of the characteristics that were transformed prior to the ANOVA.

recommended dose was observed for LLO, WLO, LLA, and WLA. The lodging + breaking index reported an increase of $2.52 \%$ when twice the dose of $\mathrm{N}$ was applied. NEP increased by 0.3 ears per plant at twice the dose of $\mathrm{N}$ compared to the recommended dose. Grain yield increased, on average, by $2.46 \mathrm{t} \mathrm{ha}^{-1}$ when twice as much nitrogen fertilizer was applied. A simple effect of applying or not ProCa was observed for the SPAD index variables, a $20 \%$ increase when the phytoregulator was applied. No lodging + breaking of corn plants was observed in hybrid AS1757 ${ }_{\text {VTPRO3 }}$ in the ProCa applied plots.

The simple effects of the factors on hybrid AG9025 $5_{\text {VTPRоз }}$ are described in Table 5. Applying twice the amount of nitrogen in the top dressing increased the relative chlorophyll content in the leaves of corn plants of hybrid AG9025 ${ }_{\mathrm{VTPRO} 3}$, as well as AS1757 $_{\text {VTPRO3, }}$ an increase of $19 \%$. The application of ProCa resulted in growth restriction of $8.6 \mathrm{~cm}$ in ear insertion height, $2.2 \mathrm{~mm}$ increments in thatch diameter, $0.7 \mathrm{~cm}$ in the width of the leaf above the ear in corn plants, and $63 \%$ in the number of ears per plant.

Pearson correlation study showed a high association of the variables involving the optical measurements (SPAD and NDVI) on the leaves opposite and above the ears, number of green leaves, regarding the productive performance and the industrial quality of the grain in hybrid AS1757 ${ }_{\text {VTPRO3 }}$ (Figure

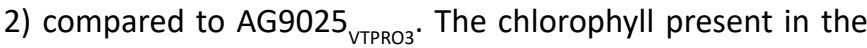
leaves can be affected by the variability of the genotypes, 
Table 3. Effects of interactions of applications of nitrogen doses and doses of prohexadione calcium in corn hybrids AS1757 ${ }_{\text {VTPRO3 }}$ and AG9025 $_{\text {VTPRO3 }}$. Lages, SC, Brazil, 2019.

\begin{tabular}{|c|c|c|c|c|c|c|}
\hline \multirow{4}{*}{ Nitrogen doses } & \multicolumn{6}{|c|}{ AS1757 $_{\text {VTPRO3 }}$} \\
\hline & \multicolumn{6}{|c|}{ ProCa } \\
\hline & Absence & Presence & Absence & Presence & Absence & Presence \\
\hline & \multicolumn{2}{|c|}{ NDVI } & \multicolumn{2}{|c|}{$\mathrm{PH}(\mathrm{cm})$} & \multicolumn{2}{|c|}{ NGL $\left(n^{0} \mathrm{pl}^{-1}\right)$} \\
\hline $1 \times\left(274 \mathrm{~kg}\right.$ of $\left.\mathrm{N} \mathrm{ha}^{-1}\right)$ & $6.3 \mathrm{bB}$ & $6.5 \mathrm{aA}$ & $237.9 a A$ & $226.3 \mathrm{bB}$ & $8.4 a A$ & $8.1 \mathrm{bA}$ \\
\hline $2 \times\left(548 \mathrm{~kg}\right.$ of $\left.\mathrm{N} \mathrm{ha}^{-1}\right)$ & $6.6 a A$ & $6.6 \mathrm{aA}$ & $235.6 a A$ & 239.9aA & $8.8 \mathrm{aB}$ & 9.9aA \\
\hline \multirow[t]{2}{*}{ MSD } & \multicolumn{2}{|c|}{0.16} & \multicolumn{2}{|c|}{9.72} & \multicolumn{2}{|c|}{0.81} \\
\hline & \multicolumn{2}{|c|}{$\operatorname{NGE}\left(n^{\circ}\right)$} & \multicolumn{2}{|c|}{$\mathrm{HW}\left(\mathrm{kg} \mathrm{100 \textrm {L } ^ { - 1 } )}\right.$} & & \\
\hline $1 \times\left(274 \mathrm{~kg}\right.$ of $\left.\mathrm{N} \mathrm{ha}^{-1}\right)$ & $362.8 \mathrm{aA}$ & $350.2 \mathrm{bA}$ & $63.8 \mathrm{aA}$ & $60.9 \mathrm{bA}$ & & \\
\hline $2 \times\left(548 \mathrm{~kg}\right.$ of $\left.\mathrm{Nha}^{-1}\right)$ & $301.6 a B$ & $501.1 \mathrm{aA}$ & $62.9 a B$ & $67.6 \mathrm{aA}$ & & \\
\hline \multirow[t]{3}{*}{ MSD } & \multicolumn{2}{|c|}{104.2} & \multicolumn{2}{|c|}{3.6} & & \\
\hline & \multicolumn{4}{|c|}{ AG9025vTPRO3 } & & \\
\hline & \multicolumn{2}{|c|}{$\operatorname{NGE}\left(n^{\circ}\right)$} & \multicolumn{2}{|c|}{ TGW (g) } & & \\
\hline $1 \times\left(274 \mathrm{~kg}\right.$ of $\left.\mathrm{N} \mathrm{ha}^{-1}\right)$ & $347.69 a A$ & $390.81 a A$ & $229.16 \mathrm{bA}$ & $210.39 \mathrm{bA}$ & & \\
\hline $2 \times\left(548 \mathrm{~kg}\right.$ of $\left.\mathrm{N} \mathrm{ha}^{-1}\right)$ & $366.25 a A$ & $326.86 \mathrm{bA}$ & $273.69 \mathrm{aA}$ & $250.57 a A$ & & \\
\hline MSD & \multicolumn{2}{|c|}{55.31} & \multicolumn{2}{|c|}{27.68} & & \\
\hline
\end{tabular}

Averages followed by the same letter, lower case in the column and upper case in the row, do not differ statistically, by Tukey test ( $p \geq 0.05)$. MSD: minimum significant difference. DR: recommended dose; DD: double the recommended dose; NDVI: normalized difference vegetation index; PH: plant height; NGL: number of green leaves; NGE: number of grains per ear; HW: hectoliter weight; TGW: thousand grains weight.

Table 4. Simple effects of $\mathrm{N}$ and ProCa on hybrid AS1757 ${ }_{\mathrm{VTPRO}}{ }$, for the variables normalized difference vegetation index (NDVI), relative chlorophyll index (SPAD), plant height (PH), ear insertion height (EIH), stem diameter (SD), number of green leaves (NGL), length and width of the leaf opposite the ear (LLO; WLO), length and width of the leaf above the ear (LLA; WLA), Lodging + breakage index (Lodg), number of ears per plant (NEP), number of grains per ear (NGE), thousand grains weight (TGW), grain yield (GY), and hectoliter weight (HW). Lages, SC, Brazil, 2019.

\begin{tabular}{|c|c|c|c|c|c|c|c|c|}
\hline \multicolumn{9}{|c|}{ Simple effect of $\mathbf{N}$ doses } \\
\hline & NDVI & SPAD & $\begin{array}{l}\mathrm{PH} \\
(\mathrm{cm})\end{array}$ & $\begin{array}{l}\text { EIH } \\
(\mathrm{cm})\end{array}$ & $\begin{array}{l}\text { SD } \\
(\mathrm{mm})\end{array}$ & $\begin{array}{c}\text { NGL } \\
\left(n^{\circ} \mathrm{pl}^{-1}\right)\end{array}$ & $\begin{array}{l}\text { LLO } \\
(\mathrm{cm})\end{array}$ & $\begin{array}{l}\text { WLO } \\
(\mathrm{cm})\end{array}$ \\
\hline $1 \times\left(274 \mathrm{~kg}\right.$ of $\left.\mathrm{N} \mathrm{ha}^{-1}\right)$ & $6.41 b$ & $34.8 \mathrm{~b}$ & $231.7 \mathrm{a}$ & $103.4 \mathrm{a}$ & $17.54 \mathrm{a}$ & $8.25 b$ & $84.2 \mathrm{~b}$ & $8.9 \mathrm{~b}$ \\
\hline \multirow[t]{2}{*}{ MSD } & 0.10 & 8.67 & 6.87 & 6.20 & 5.87 & 0.57 & 2.3 & 0.5 \\
\hline & $\begin{array}{l}\text { LLA } \\
(\mathrm{cm})\end{array}$ & $\begin{array}{l}\text { WLA } \\
(\mathrm{cm}) \\
\end{array}$ & $\begin{array}{c}\text { Lodg } \\
(\%)\end{array}$ & $\begin{array}{c}\text { NEP } \\
\left(n^{\circ} \mathrm{pl}^{-1}\right)\end{array}$ & $\begin{array}{l}\text { NGE } \\
\left(n^{\circ}\right) \\
\end{array}$ & $\begin{array}{c}\text { TGW } \\
\text { (g) }\end{array}$ & $\begin{array}{c}\text { GY } \\
\left(t^{\text {h }} a^{-1}\right) \\
\end{array}$ & $\begin{array}{c}\mathrm{HW} \\
\left(\mathrm{kg} \mathrm{100L}^{-1}\right)\end{array}$ \\
\hline $2 \times\left(548 \mathrm{~kg}\right.$ ofe $\left.\mathrm{N} \mathrm{ha}^{-1}\right)$ & $79.7 \mathrm{a}$ & $9.58 \mathrm{a}$ & $2.98 \mathrm{a}$ & 0.93 a & $401.3 \mathrm{a}$ & $245.3 \mathrm{a}$ & $6.82 \mathrm{a}$ & $65.2 \mathrm{a}$ \\
\hline MSD & 3.5 & 0.6 & 2.44 & 0.22 & 73.7 & 35.7 & 2.35 & 2.30 \\
\hline \multicolumn{9}{|c|}{ Simple ProCa effect } \\
\hline & NDVI & SPAD & $\begin{array}{c}\mathrm{PH} \\
(\mathrm{cm}) \\
\end{array}$ & $\begin{array}{l}\text { EIH } \\
(\mathrm{cm}) \\
\end{array}$ & $\begin{array}{c}\mathrm{SC} \\
(\mathrm{mm}) \\
\end{array}$ & $\begin{array}{c}\text { NGL } \\
\left(n^{\circ} \mathrm{pl}^{-1}\right) \\
\end{array}$ & $\begin{array}{l}\text { LLO } \\
(\mathrm{cm}) \\
\end{array}$ & $\begin{array}{l}\text { WLO } \\
(\mathrm{cm}) \\
\end{array}$ \\
\hline Absence & $77.2 \mathrm{a}$ & $8.9 a$ & $3.44 \mathrm{a}$ & $0.73 a$ & $332.2 b$ & $239.9 a$ & $5.16 \mathrm{a}$ & $63.3 a$ \\
\hline Presence & $78.2 \mathrm{a}$ & $9.3 \mathrm{a}$ & $0.00 \mathrm{~b}$ & $0.80 \mathrm{a}$ & $425.6 \mathrm{a}$ & $267.3 \mathrm{a}$ & $6.02 \mathrm{a}$ & $64.3 \mathrm{a}$ \\
\hline MSD & 3.5 & 0.6 & 2.44 & 0.22 & 73.7 & 35.7 & 2.35 & 2.30 \\
\hline
\end{tabular}

Averages followed by the same letter, in the column, do not differ statistically, by Tukey test $(p \geq 0.05)$. MSD: minimum significant difference.

evaluation stages, sampled leaves, crop management and development, and especially the form, amount, and timing of nitrogen fertilizer application. The increase in chlorophyll content in the leaves at the application of twice the recommended dose of nitrogen in both hybrids tested is due to the nitrogen present in the chlorophyll for photosynthetic activity (Figure 2). From the higher number of correlations (significant by t-test; $\mathrm{p}<0.05$ ) observed in hybrid AS1757 ${ }_{\text {VTPRO3 }}$ it proved more responsive to nitrogen treatments, ProCa and in $\mathrm{N} \times$ ProCa interactions, than $\mathrm{AG} 9025_{\mathrm{VTPRO}}$.

\section{Discussion}

The relative chlorophyll content associated with NDVI is an indication of conversion of light energy into chemical energy, i.e. into photoassimilates (Kolling et al., 2019). Thus, 
Table 5. Simple effects of $\mathrm{N}$ and ProCa on hybrid AG9025 ${ }_{\mathrm{VTPRO}}$, for the variables normalized difference vegetation index (NDVI), relative chlorophyll index (SPAD), plant height $(\mathrm{PH})$, ear insertion height (EIH), stem diameter (SD), number of green leaves (NGL), length and width of the leaf opposite the ear (LLO; WLO), length and width of the leaf above the ear (LLA; WLA), Lodging + breakage index (Lodg), number of ears per plant (NEP), number of grains per ear (NGE), thousand grains weight (TGW), grain yield (GY), and hectoliter weight (HW). Lages, SC, Brazil, 2019.

\begin{tabular}{|c|c|c|c|c|c|c|c|c|}
\hline \multicolumn{9}{|c|}{ Simple effect of $\mathbf{N}$ doses } \\
\hline & NDVI & SPAD & $\begin{array}{l}\mathrm{PH} \\
(\mathrm{cm}) \\
\end{array}$ & $\begin{array}{l}\text { EIH } \\
(\mathrm{cm}) \\
\end{array}$ & $\begin{array}{c}\text { SD } \\
(\mathrm{mm}) \\
\end{array}$ & $\begin{array}{c}\text { NLG } \\
\left(n^{\circ} \mathrm{pl}^{-1}\right)\end{array}$ & $\begin{array}{l}\text { LLO } \\
(\mathrm{cm}) \\
\end{array}$ & $\begin{array}{l}\text { WLO } \\
(\mathrm{cm}) \\
\end{array}$ \\
\hline $1 \times\left(274 \mathrm{~kg}\right.$ of $\left.\mathrm{Nha}^{-1}\right)$ & $6.81 \mathrm{a}$ & $41.73 b$ & $216.4 \mathrm{a}$ & $103.0 \mathrm{a}$ & $20.7 \mathrm{a}$ & $9.65 \mathrm{a}$ & $91.2 \mathrm{a}$ & $9.2 \mathrm{a}$ \\
\hline $2 \times\left(548 \mathrm{~kg}\right.$ of $\left.\mathrm{Nha}^{-1}\right)$ & $6.82 \mathrm{a}$ & $51.68 \mathrm{a}$ & $216.3 \mathrm{a}$ & $106.4 \mathrm{a}$ & $22.5 \mathrm{a}$ & $10.43 a$ & $93.2 \mathrm{a}$ & $9.5 \mathrm{a}$ \\
\hline \multirow[t]{2}{*}{ MSD } & 0.26 & 7.30 & 13.5 & 5.28 & 1.97 & 0.82 & 8.1 & 0.8 \\
\hline & $\begin{array}{l}\text { LLA } \\
(\mathrm{cm}) \\
\end{array}$ & $\begin{array}{l}\text { WLA } \\
(\mathrm{cm}) \\
\end{array}$ & $\begin{array}{l}\text { Lodg } \\
(\%) \\
\end{array}$ & $\begin{array}{c}\text { NEP } \\
\left(n^{\circ} \mathrm{pl}^{-1}\right) \\
\end{array}$ & $\begin{array}{l}\text { NGE } \\
\left(n^{\circ}\right) \\
\end{array}$ & $\begin{array}{c}\text { TGW } \\
\text { (g) } \\
\end{array}$ & $\begin{array}{c}\text { GY } \\
\left(t^{\text {ha-1) }}\right) \\
\end{array}$ & 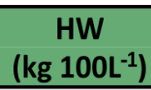 \\
\hline $1 \times\left(274 \mathrm{~kg}\right.$ of $\left.\mathrm{Nha}^{-1}\right)$ & $79.7 \mathrm{a}$ & $8.4 \mathrm{a}$ & $0.86 \mathrm{a}$ & $0.59 \mathrm{a}$ & $346.5 \mathrm{a}$ & $242.0 \mathrm{a}$ & $2.46 \mathrm{a}$ & $60.6 \mathrm{a}$ \\
\hline $2 \times\left(548 \mathrm{~kg}\right.$ of $\left.\mathrm{Nha}^{-1}\right)$ & $81.5 \mathrm{a}$ & $8.8 \mathrm{a}$ & $2.27 \mathrm{a}$ & $0.70 \mathrm{a}$ & $369.2 \mathrm{a}$ & $239.9 \mathrm{a}$ & $2.75 a$ & $58.8 \mathrm{a}$ \\
\hline MSD & 10.5 & 0.67 & 3.26 & 0.16 & 39.1 & 19.57 & 0.52 & 4.22 \\
\hline \multicolumn{9}{|c|}{ Simple ProCa effect } \\
\hline & NDVI & SPAD & $\begin{array}{c}\mathrm{PH} \\
(\mathrm{cm})\end{array}$ & $\begin{array}{l}\text { EIH } \\
(\mathrm{cm})\end{array}$ & $\begin{array}{c}\text { SD } \\
(\mathrm{mm})\end{array}$ & $\begin{array}{c}\text { NLG } \\
\left(n^{\circ} \mathrm{pl}^{-1}\right)\end{array}$ & $\begin{array}{l}\text { LLO } \\
(\mathrm{cm})\end{array}$ & $\begin{array}{l}\text { WLO } \\
(\mathrm{cm})\end{array}$ \\
\hline Absence & $6.76 \mathrm{a}$ & $46.8 \mathrm{a}$ & $216.3 \mathrm{a}$ & $109.0 \mathrm{a}$ & $20.5 \mathrm{~b}$ & $9.84 a$ & $89.9 a$ & $8.9 \mathrm{a}$ \\
\hline Presence & $6.86 a$ & $46.6 \mathrm{a}$ & $216.3 \mathrm{a}$ & $100.4 \mathrm{~b}$ & $22.7 a$ & $10.25 \mathrm{a}$ & $94.5 a$ & $9.7 \mathrm{a}$ \\
\hline \multirow[t]{2}{*}{ MSD } & 0.26 & 7.30 & 13.5 & 5.28 & 1.97 & 0.82 & 8.1 & 0.8 \\
\hline & $\begin{array}{l}\text { LLA } \\
(\mathrm{cm})\end{array}$ & $\begin{array}{l}\text { WLA } \\
(\mathrm{cm})\end{array}$ & $\begin{array}{l}\text { Lodg } \\
\text { (\%) }\end{array}$ & $\begin{array}{c}\text { NEP } \\
\left(n^{\circ} \mathrm{pl}^{-1}\right)\end{array}$ & $\begin{array}{l}\text { NGE } \\
\left(\mathrm{n}^{\circ}\right)\end{array}$ & $\begin{array}{c}\text { TGW } \\
\text { (g) }\end{array}$ & $\begin{array}{c}\text { GY } \\
\left(t \text { ha }^{-1}\right)\end{array}$ & $\begin{array}{c}\mathrm{HW} \\
\left(\mathrm{kg} \mathrm{100L^{-1 } )}\right.\end{array}$ \\
\hline Absence & $79.7 a$ & $8.3 b$ & $0.00 a$ & $0.50 \mathrm{~b}$ & 356.9 a & $251.4 a$ & $2.60 a$ & 59.9 a \\
\hline Presence & $81.5 \mathrm{a}$ & $9.0 \mathrm{a}$ & $3.14 \mathrm{a}$ & $0.79 a$ & $358.8 \mathrm{a}$ & $230.5 b$ & $2.61 \mathrm{a}$ & $59.5 \mathrm{a}$ \\
\hline MSD & 10.5 & 0.67 & 3.26 & 0.16 & 39.1 & 19.57 & 0.52 & 4.22 \\
\hline
\end{tabular}

Averages followed by the same letter, in the column, do not differ statistically, by Tukey test ( $p \geq 0.05)$. MSD: minimum significant difference.

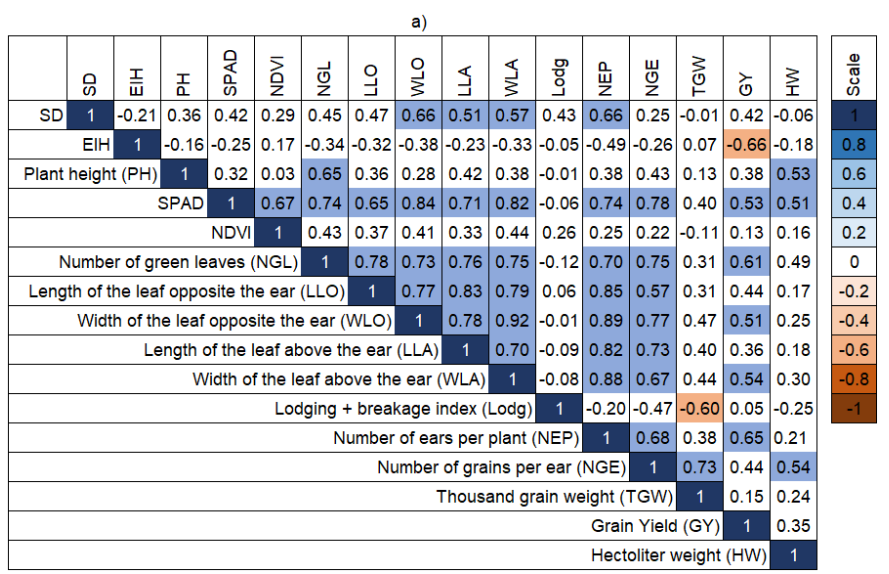

Abbrevviations: SD: stem diameter; EIH: ear insertion height; PH: plant height, NDVI: normalized difference vegetation index; SPAD: relative chlorophyll index; NGL: number of green leaves; LLO, WLO: length and width of the leaf opposite the ear, LLA, WLA: length and width of the leaf above the ear; LOGD $\mathrm{i}$ : Lodging + breakage index; NEP: number of ears per plant; NGE: number of grains per ear; TGW: thousand grains weight; GY: grain yield; HW: hectoliter weight.

Figure 2. Pearsons correlation values between morphoagronomic characters in the hybrid a) AS1757 PRO3, and b) AG9025 $\mathrm{PRO3}$, in the average of two nitrogen doses and absence/presence of ProCa application.

nitrogen acts in the structural and functional integrity of photosynthesis, and by being part of proteins and chlorophylls, and also acts in the maintenance and preservation of source tissues, prolonging longevity, and delaying leaf senescence (Taiz et al., 2017).

Nitrogen is part of the chlorophyll molecule directly influencing its biosynthesis and consequently the shade of green coloration of light absorption by the canopy, together with leaf area and leaf angle that under conditions of greater nitrogen availability, can optimize photosynthetic activity, and consequently the integration of molecular structures and the action in some steps of the reactions that provide the synthesis of chlorophyll pigments that confer green color (Taiz et al., 2017). The influence of ProCa on the increase in chlorophyll content in hybrid AS1757 PRO3 can be explained by the increase in chlorophyll content present in the leaf tissues per unit area and/or volume, a reflection of the inhibition of vegetative growth with the application of the phytoregulator. This response was also observed by Espindula et al. (2009) when applying the phytoregulator trinexapac-ethyl to the wheat cultivar Pioneiro. 
Regarding $\mathrm{PH}, \mathrm{EIH}$, and SD, lower heights and larger diameters may be associated with a lower risk of lodging and/ or cane breakage. Dartora et al. (2013) reported that corn plant height obtains high variance when subjected to increasing doses of $\mathrm{N}$, and that the behavior of growth curves varies according to the phenological stage of the crop. When in the vegetative stage, there is a stabilization near $120 \mathrm{~kg}$ of $\mathrm{N} \mathrm{ha}^{-1}$, while in the reproductive stage this curve is linearly increasing. According to Zagonel \& Ferreira (2013) plant height is the main phytometric characteristic that the application of vegetative growth inhibiting phytoregulators alters. Mendes Fagherazzi et al. (2018) reported that the phenological stage of the crop at which the phytoregulator was applied also influences the final height of corn plants, being of greater sensitivities to the product when applied to corn plants between the V6 and V7 stages. In addition, factors such as species, genotype, canopy architecture, and climatic conditions and management also influence its action. In study on rice crop ( $\mathrm{Na}$ et al., 2011), flax (Kim et al., 2018) and wheat (Stefen et al., 2014) corroborate with the results of this research on the efficiency of ProCa in restricting the longitudinal growth of the main stem of the plant. The lack of response in $\mathrm{PH}$ in hybrid AG9025 $5_{\text {VTPRO3 }}$ may be due to its super-precociousness, a cycle characterized by a lower requirement in thermal heat units to reach flowering, and one in which it generally exhibits less thatch growth. However, ProCa restricted growth in EIA and increased CD in $\mathrm{AG} 025_{\mathrm{VTPRO}_{3}}$, which may have compensated for the final plant height due to the growth of internodes positioned above the ear.

According to Leolato et al. (2017) smaller EIG, from an agronomic point of view, would be more advantageous because they allow the center of gravity to be closer to the ground, being more balanced, favoring nutrient uptake, synthesis of assimilates for grain production, and coupled with the increase in thatch diameter, reduces the pre-disposition to lodging and thatch breakage. Stronger basal internodes with larger diameters are important traits for evaluating thatch lodging in cereals (Ye et al., 2015). In the present study, ProCa significantly increased basal internode diameter of the thatch in hybrid AG9025 ${ }_{\text {VTPRO3 }}$, however, due to the low mean lodging values and lower final plant heights, the change in SD and $\mathrm{PH}$ did not allow confrontation as to lodging. Na et al. (2011) observed that the rate of lodged plants in rice crop was significantly reduced with the application of ProCa alone or in association with other phytoregulators. This performance of the hybrids proves the efficiency of prohexadione in acting on the intercalary meristems of corn plants and preventing the complete elongation of internode length, which restricted the complete growth in plant height $\left(\mathrm{AS}_{1757_{\text {VTPRO3 }}}\right.$ ) and in ear insertion height (AG9025 ${ }_{\text {VTPRO3 }}$ ).

The compensatory effect on the components number of grains per ear and thousand grains weight is of fundamental importance for the technical recommendations of nitrogen fertilization aiming to increase grain yield. Nitrogen influence on traits such as NGE and TGW is also depicted, contributing to increased protein percentage and in ear weight gain, providing higher yields (Lange et al., 2014). Based on the observations regarding the number of grains per ear and thousand grains weight Pinheiro et al. (2018) observed no significant difference between treatments with ProCa, however, the phytoregulator at a dose of $200 \mathrm{~g}$ i.a. ha ${ }^{-1}$ provided a $7 \%$ increase when compared to the control ( $0 \mathrm{~g}$ i.a. $\left.\mathrm{ha}^{-1}\right)$, a fact also verified in this work in hybrid AS1757 ${ }_{\text {VTPRO3 }}$.

Regarding HW, Stefen et al. (2014) observed in the wheat crop, and extending this research to the corn crop, this measurement is correlated with grain size and protein content, in addition to the fact that a greater grains weight obtains higher $\mathrm{HW}$ values, since $\mathrm{HW}$ is a relationship between grain weight and volume occupied by these grains, it can also serve as an indirect indicator of storage volume, i.e. higher HW means lower storage volume, a fact observed in Pearson correlation (Figure 2), regardless of the hybrid (Figure 2).

In the present study, the grain yield of hybrid AS1757 ${ }_{\text {VTPRO3 }}$ was higher on application of twice the recommended dose of $\mathrm{N}$. This may be due to nitrogen tending greater security to high corn yields, which is related to the establishment of reproductive drain capacity, and this as a function of grain number and size. According to Souza \& Soratto (2006) and Carneiro Junior et al. (2021) the number of kernels per ear correlates more strongly with corn grain yield than any other productive component. In addition, biological yield estimation also stands out as a simplified assessment of the complex growth processes and environmental influences that affect grain yield in corn plants.

\section{Conclusions}

Side dressing application of twice the recommended nitrogen fertilization increases the grain yield in the AS1757 $_{\text {VTPRO3 }}$ hybrid, however, it intensifies the lodging and breakage index in late-season maize plants in southern Brazil.

The application of ProCa in maize plants at stage V7 is effective in reducing lodging and broken plants in early hybrid (AS1757 ${ }_{\text {VTPRO3 }}$ ), as well as increasing stalk diameter values in super-early hybrid $\left(\mathrm{AG} 025_{\text {VTPRO3 }}\right.$ ), but it does not affect the grain yield of the crop.

The application of ProCa associated with twice the recommended nitrogen fertilization is responsive in the AS1757 $_{\text {VTPRO3 }}$ hybrid and efficient in increasing relative values of NDVI, number of photosynthetically active leaves, grains per ear and its weight of hectoliter.

\section{Acknowledgments}

The authors would like to thank CNPq, CAPES, FAPESC/ UDESC/PAP and UNIEDU/FUMDES for their financial support to the present research and the scholarships granted to the authors.

\section{Compliance with Ethical Standards}

Author contribution: Conceptualization: CAS, JFCCJ, MGP; Data curation: CAS, JFCCJ; Formal analysis: MGP, LS, Funding acquisition: CAS, LS; Investigation: JFCCJ, RK, AFB, EJS; 
Methodology: CAS, MGP, JFCCJ, Project administration: CAS; Resources: CAS; Supervision: CAS, JFCCJ; Validation: CAS, RK, ERS; AFB, LS; Visualization: CAS; Writing - original draft: JFCCJ; Writing - review \& editing: JFCCJ, CAS, MGP, LS.

Conflict of interest: The authors declare no conflict of interest.

Source funding: Conselho Nacional de Desenvolvimento Científico e Tecnológico (CNPq), Coordenação de Aperfeiçoamento de Pessoal de Nível Superior - Brasil (CAPES) Finance Code 001, FAPESC/UDESC/PAP and UNIEDU/FUMDES.

\section{Literature Cited}

Carneiro Junior, J. F. C.; Souza, C. A.; Pinheiro, M. G.; Silva, E. R.; Silva, A. L. P. Morpho-physiological responses of maize hybrids as a function prohexadione calcium doses applied in the vegetative phase. Bulgarian Journal of Agricultural Science, v.27, n.1, 2021. https://journal.agrojournal.org/page/download. php?articleID=3259. 22 Jun. 2021.

Comissão de Química e Fertilidade do Solo - RS/SC - CQFS-RS/SC. Manual de adubação e de calagem para os estados do Rio Grande do Sul e Santa Catarina. Porto Alegre: SBCS - Núcleo Regional Sul; UFRGS, 2016.400 p.

Companhia Nacional de Abastecimento - Conab. Acompanhamento da Safra Brasileira de Grãos, safra 2019/2020. Brasília: Conab, 2020. 114p. (v. 7 - Safra 2019/20, n. 5 - Quinto levantamento). https://www.conab.gov.br/info-agro/safras/graos/boletim-dasafra-de-graos/item/download/30665_95761ce4bcf9700b5d4e b70be1d08155. 02 Aug. 2020.

Dartora, J.; Guimarães, V. F.; Marini, D.; Sander, G. Adubação nitrogenada associada à inoculação com Azospirillum brasilense e Herbaspirillum seropedicae na cultura do milho. Revista Brasileira de Engenharia Agrícola e Ambiental, v.17, n.10, p. 1023-1029, 2013. https://doi.org/10.1590/S1415-43662013001000001 .

Espindula, M. C.; Rocha, V. S.; Fontes, P. C. R.; Silva, R. C. C.; Souza, L. T. Effect of nitrogen and trinexapac-ethyl rates on the SPAD index of wheat leaves. Journal of Plant Nutrition, v.32, n.11, p.19561964, 2009. https://doi.org/10.1080/01904160903245113.

Ferreira, D. F. Sisvar: a guide for its bootstrap procedures in multiple comparisons. Ciência e Agrotecnologia, v.38, n.2, p. 109-112, 2014. https://doi.org/10.1590/S1413-70542014000200001.

Kim, S. K.; Han, C.; Shin, J.; Kwon, T. Effects of paclobutrazol and prohexadione-ca on seed yield, and content of oils and gibberellin in flax grown in a greenhouse. Korean Journal of Crop Science, v.63, n.3, p.265-271, 2018. https://doi.org/10.7740/ kjcs.2018.63.3.265.

Kolling, D. F.; Sangoi, L.; Leolato, S. L.; Panison, F.; Coelho, A. E.; Kuneski, H. F. Can an increase in nitrogen rate mitigate damages caused by uneven spatial distribution of maize plants at the sowing row? Acta Scientiarum. Agronomy, v.41, n.1, p.1-9, 2019. https://doi.org/10.4025/actasciagron.v41i1.39874.

Lange, A.; Caione, G.; Shoninger, E. L.; Silva, R. G. Produtividade de milho safrinha em consórcio com capim-marandu em função de fontes e doses de nitrogênio em cobertura. Revista Brasileira de Milho e Sorgo, v.13, n.1, p.35-47, 2014. https://doi. org/10.18512/1980-6477/rbms.v13n1p35-47.
Leolato, L. S. Sangoi, L.; Durli, M. M.; Panison, F.; Voss, R. Growth regulator and maize response to the increase in plant density. Pesquisa Agropecuária Brasileira, v.52, n.11, p.997-1005, nov., 2017. https://doi.org/10.1590/s0100-204×2017001100005.

Ministério da Agricultura, Pecuária e Abastecimento - Mapa. Agrofit: sistemas de agrotóxicos fitossanitários. 2019. http://agrofit. agricultura.gov.br/agrofit_cons/principal_agrofit_cons. 24 Jul. 2019.

Mendes Fagherazzi, M.; Souza C. A.; Stefen, D. L. V.; Zanesco, P. R.; Junkes, G. V.; Coelho, C. M. M.; Sangoi, L. Phenological sensitivity of two maize cultivars to trinexapac- ethyl. Planta Daninha, v.36, n.1, p.1-10, 2018. https://doi.org/10.1590/S010083582018360100012.

Na, C.; Hamayun, M.; Khan, A. L.; Kim, Y.; Choi, K.; Kang, S.; Kim, S.; Kim, J.; Won J.; Lee, I. Influence of prohexadione-calcium, trinexapac-ethyl and hexaconazole on lodging characteristic and gibberellin biosynthesis of rice (Oryza sativa L.). African Journal of Biotechnology, v.10, n.61, p.13097-13106, 2011. https://doi. org/10.5897/AJB11.746.

Pinheiro, M. G.; Souza, C. A.; Carneiro Junior, J. F. C.; Silva, E. R.; Kandler, R. Prohexadione-Calcium and nitrogen topdressing fertilisation on productive performance of maize with late sowing. International Journal of Plant \& Soil Science, v.25, n.4, p.1-10, 2018. https://doi.org/10.9734/IJPSS/2018/45254.

Pricinotto, L. F. Zucareli, C.; Fonseca, I. C. B.; Oliveira, M. A.; Ferreira, A. S.; Spolaor, L. T. Trinexapac-ethyl in the vegetative and reproductive performance of corn. African Journal of Agricultural Research, v. 10, n. 14, p. 1735-1742, abr., 2015. https://doi. org/10.5897/AJAR2014.8613.

R Core Team. R: A language and environment for statistical computing, versão 3.6.1. Vienna: R Foundation for Statistical Computing, 2019. https://www.R-project.org. 25 Jun. 2019.

Rademacher, W. Chemical regulators of gibberellin status and their application in plant production. In: Hedden, P.; Thomas, S.G. (Eds.). Annual plant reviews, volume 49: Gibberellins. Oxford: John Wiley \& Sons, 2016. Chap. 12, p. 359-404. https://doi. org/10.1002/9781119210436.ch12.

Rademacher, W. Plant growth regulators: backgrounds and uses in plant grass species development. Journal of Plant Growth Regulation, v.34, n.4, p.845-872, 2015. https://doi.org/10.1007/ s00344-015-9541-6.

Ritchie, S. W.; Hanway, J. J.; Benson, G. O. How a corn plant develops. Ames: lowa State University of Science and Technology, 1993. 26p. (lowa State University of Science and Technology. Special Report, 48).

Sangoi, L.; Silva, P. R. F.; Pagliarini, N. H. F. Estratégias de manejo da adubação nitrogenada em milho na região sul do Brasil. Lages: Graphel, 2016. 122 p.

Santos, H. G.; Jacomine, P. K. T.; Anjos, L. H. C.; Oliveira, V. A.; Lumbreras, J. F.; Coelho, M. R.; Almeida, J. A.; Cunha, T. J. F.; Oliveira, J. B. Sistema brasileiro de classificação de solos. 3.ed. Brasília: Embrapa Solos, 2013. 353 p.

Souza, E. F. C.; Soratto, R. P. Efeito de fontes e doses de nitrogênio em cobertura, no milho safrinha, em plantio direto. Revista Brasileira de Milho e Sorgo, v.5, n.3, p.395-405, 2006. https://doi. org/10.18512/1980-6477/rbms.v5n03p\%25p. 
Stefen, D. L. V.; Souza, C. A.; Coelho, C. M. M.; Tormem, M. E.; Zanesco, P. R.; Casa, R. T.; Sangoi, L.; Nunes, F. R. Adubação nitrogenada associada ao emprego de reguladores de crescimento em trigo cv. Mirante. Revista de Ciências Agroveterinárias, v.13, n.1, p.30-39, 2014. http://www.revistas.udesc.br/index.php/agroveterinaria/ article/view/5171. 02 Aug. 2020.

Taiz, L.;Zeiger, E.; Moller, I. M.; Murphy, A. Fisiologia e desenvolvimento vegetal. 6.ed. Porto Alegre: Artmed, 2017. 888 p.
Ye, D. L.; Zhang, Y. S.; Al-Kaisi, M. M.; Duan, L. S.; Zhang, M. C.; Li, Z. H. Ethephon improved stalk strength associated with summer maize adaptations to environments differing in nitrogen availability in the North China Plain. Journal of Agricultural Science, v. 154, n. 1, p. 960-977, 2015. https://doi.org/10.1017/S0021859615000829.

Zagonel, J.; Ferreira, C. Doses e época de aplicação de regulador de crescimento em híbridos de milho. Planta Daninha, v. 31, n. 2, p. 395 402, 2013. https://doi.org/10.1590/S0100-83582013000200017. 